DE DE GRUYTER OPEN
Przedsiębiorczość i Zarządzanie Entrepreneurship and Management University od Social Sciences Publishing House

ISSN 1733-2486

Volume XVI, Issue 2, pp. 133-144

DOI 10.1515/eam-2015-0022

Remigiusz Tunowski

Gdansk School of Banking

\title{
Business Intelligence in Organization. Benefits, Risks and Developments
}

\begin{abstract}
:
Based on the literature review, significant benefits have been identified out of the implementation of Business Intelligence. However, risks have been also discovered, and they were mainly connected with an improper change management during the process of the $\mathrm{BI}$ systems implementation. Further direction for a development of $\mathrm{BI}$ system has been discussed, focusing in particular on maturity models available in the literature. The paper highlights the fact that maturity models currently available in the literature do not take comprehensively into account all aspects of the development of $\mathrm{BI}$ in organizations. Therefore, there is a need for further research in this field of science.
\end{abstract}

Key words: Business Intelligence, benefits, risks, developments, maturity models.

\section{Introduction}

Business Intelligence (BI) systems have become an integral part of running a business in the twenty-first century due to constantly increasing needs of organizations in the field of analysis, interpretation and data processing.

The definition of Business Intelligence refers to a broad concept of business intelligence which is designed to support and to improve decision making, and which, in turn, should lead to increase in the efficiency of an organization. However, the implementation of a BI system by itself cannot guarantee satisfactory results. To be successful, the management team has to make a se- 
ries of decisions aimed at improving an organization, based on information from a BI system.

The purpose of this study is to identify the benefits and risks of the BI systems implementation in an organization and to discuss future direction of the Business Intelligence systems based on a review of the current scientific achievements.

The first part of this article highlights the important aspects associated with the implementation of the BI systems: it discusses the potential risks which may result in a failure of the BI project, while on the other hand, it also specifies a number of benefits which arise due to implementing a BI system.

The second part focuses on the directions for a development of the BI systems. Thirteen maturity models are compared and an attempt is made to determine whether or not they fully meet the needs of today's organizations. This is done in the context of determining the precise direction for development of the BI systems.

\section{Business Intelligence for an organization - the benefits and risks}

Key benefits and risks for an organization are created by the process of implementation and use of the BI systems. Risks are associated with engaging additional resources of an organization it the very process of implementation of BI, while the benefits occur only when such engagement gives measurable outcomes.

"It's not just a data processing technique, but also management techniques, personnel motivation and stimulating real demand for information" writes P. Adamczewski on the process of implementation of Business Intelligence. The author agrees with Adamczewski's opinion that situation in the market is that of increased availability of cheaper and more efficient BI solutions, however at the same time there is a lack of concept of their use [Adamczewski 2012, pp. 65-75]. This conclusion is also confirmed by S. and W. Williams who hold that Business Intelligence systems bring a completely new analytical capabilities for an organization, however achieving success is contingent on a good game of the whole team until the end of a match. Therefore, the timing of implementation of BI can be compared to going on the break after the first half of a football match in the role of leading the team. [Williams and Williams 2003].

Moreover, the BI project can be successful in the financial sense but it may cause a loss on other projects. This can happen, for example, as a result of the involvement of key employees in the implementation of BI which can lead to 
a decrease in the efficiency of their "business as usual" activities. Successful implementation of $\mathrm{BI}$ in an organization is dependent on a professional change management, because the implementation itself (understood as intangible assets) leads to a reduction of a company's value due to the fact that it consumes resources of an organization [Surma 2009].

Furthermore, P. Adamczewski also points out that the implementation of Business Intelligence can favor reorientation of a company on the path where the goal is to become "intelligent organization". This term refers to a learning organization which is based on philosophy of knowledge management [Koronios and Yeoh 2010, p. 35]. Such an organization has an ability to acquire knowledge and to use it to improve efficiency and competitiveness [Orzechowski 2008, p. 143].

Research of Bara and N. D. Knezevic is an extension of the above idea. The researchers discuss the learning process which is possible through the use of Business Intelligence technology since details of the actions taken (as a result of the BI use) are stored in a data source of a BI system. At the same time, these researchers point out a significant factor of latency in the decision making process. They distinguish three types of latency: 1) data latency - when data are available in the data warehouse; 2) analysis latency - when data is available to applications and users ; 3) decision latency - period of time between receiving information and making a decision. There are two kinds of gaps between the time needed for each of these three stage: the gap of knowledge and a decision making gap [Bara and Knezevic 2013, pp. 27-42]. This phenomenon is shown on Figure 1 for better visualization.

\section{Figure 1. Gap in knowledge and decision-making}

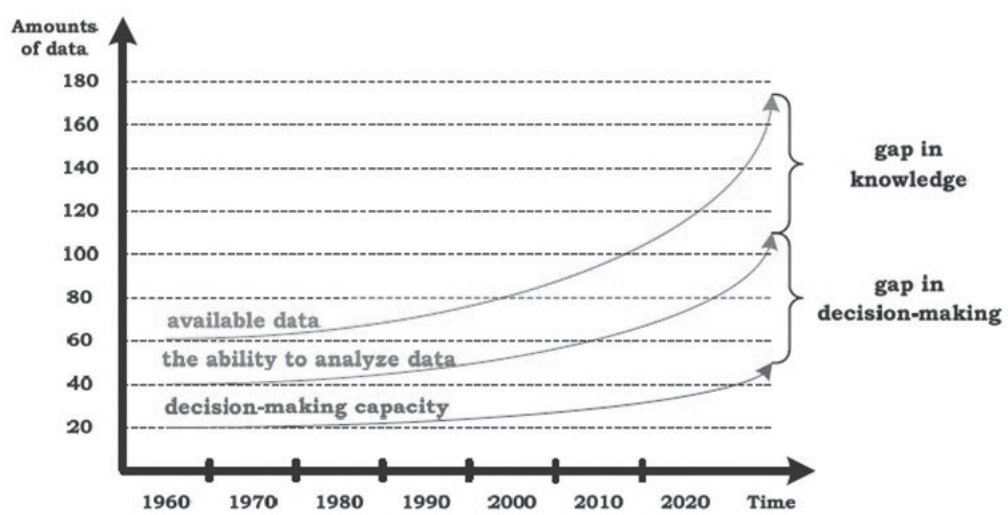

Source: Bara D., Knezevic N., The impact of right-time business intelligence on organizational behavior, "Interdisciplinary Management Research", 2013, vol. 9, p. 36. 
As indicated by the literature, the following relationship occurs with a development of technology: possibilities for analysis and decision-making capabilities using large data sets do not grow as fast as the ability to collect data. There is much more data stored than current systems are able to analyze. Accordingly, the ability to identify an organization's relevant data becomes an important skill. In 2005, Y. Chen developed the method of valuation of the data set. In his method, usage counters, scalability rates and weight of the stages of life are arbitrarily determined in such a way that the oldest periods are granted to the smallest value. The disadvantage of this method is the high degree of complexity, the need to store multiple usage counters and arbitrary setting of parameters [Chen 2005].

However, in 2007 a method was proposed which calculates the likelihood of using harvest in the future on the basis of three parameters: file age range (in days), number of the registered file access operations (ranges) and type of a file. Unfortunately, due to the high degree of complexity and the need to determine the appropriate criteria of grouping, this method is not suitable for universal use [Turczyk, Gropl, Libau and Steinmetz 2007].

The next method has been proposed by $\mathrm{H}$. Jin in 2008, where the valuation of the data set use parameters reflecting the supply side (size and speed of access to the data set) and demand side (expected period of use of the data set in the future, the number of users of the data set in the past, the relationship between the number of stored data and the number of accesses in the day). The disadvantage of the above method, in addition to its complexity, lies in the need to maintain multiple counters [Jin, Xiong and Wu 2008].

To sum up, all the above mentioned methods have one fundamental disadvantage: their practical implementation is very difficult. Importantly, J. Swacha has developed an original data set valuation method which, unlike the previously described methods, is simple in a practical implementation and automation. Its use does not require large data volume and it has only two parameters: time and frequency of use [Swacha 2011, pp. 108-119].

Wrong decisions, often made on the basis of intuition, may be critical for the company. Before the era of computer technology decisions were made mainly on the basis of estimations, assumptions and intuition [Maria 2009, pp. 996-1000]. Nowadays, thanks to the BI systems, we can move away from this type of practice to make decisions based on hard data gathered from information systems. However, the process of data collection and processing is very time-consuming.

As it is shown in Figure 2, organizations are able to reduce significantly the time needed for data collection, processing and analysis of data through the 
implementation of BI [Bara and Knezevic 2013, pp. 27-42]. In organizations which do not use the BI systems, $80 \%$ of analysts' time is spent on data collection, and only $20 \%$ for analysis.

\section{Figure 2. The Benefit of Reducing Latency}

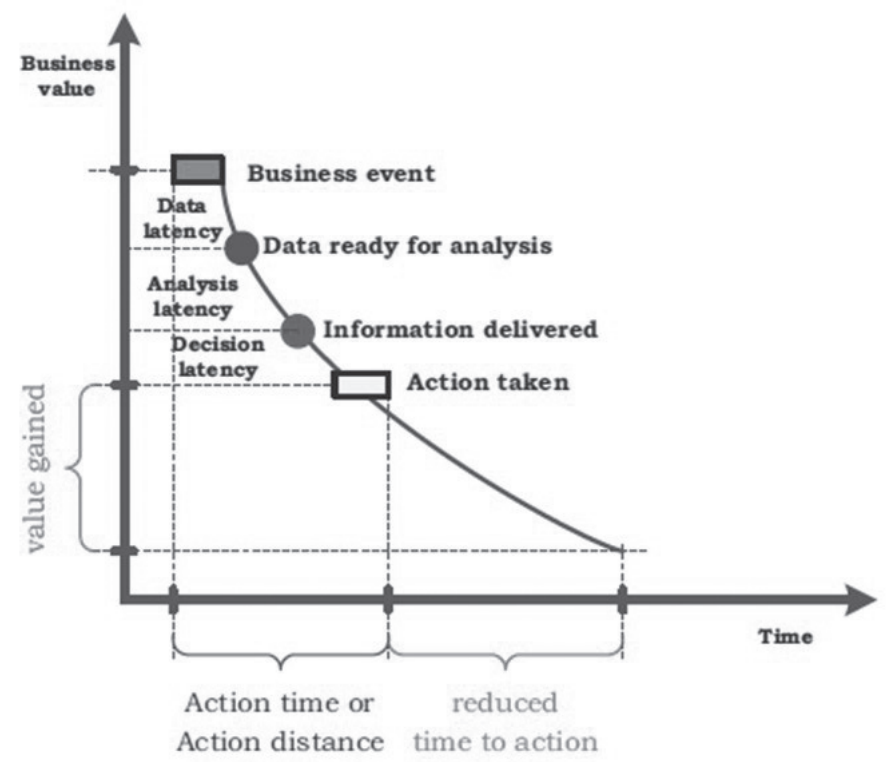

Source: Bara D., Knezevic N., The impact of right-time business intelligence on organizational behavior, "Interdisciplinary Management Research", 2013, vol. 9, page 33.

Research conducted by D. Bara and N. D. Knezevic indicates that through the use of BI systems the time spent on data collection can be reduced by 3.5 times. As a result, the employees can spend more time on analysis and decision-making.

The aforementioned increase in employees' efficiency is also possible through the use of advanced visualization available in Business Intelligence systems which is characterized by increased information capacity. One of the examples of such visualization is a managerial dashboard. As evidenced by research conducted by the University of Economics in Wroclaw and UNIT4 Teta BI Center (a company which focuses on the development of intelligent dashboard for managers of SMEs), managerial dashboards can monitor such elements as financial ratios, credit standing, data mining, predictions, simulations, clustering, alerts and decision rules [Korczak, Dudycz and Dyczkowski 2012, pp. 27-37]. Unfortunately, from the point of view of the managers of small and medium-sized enterprises, the techniques mentioned above are cur- 
rently inaccessible due to high costs of implementation of BI systems. However with the development of science, the availability of such solutions should be increased in the future.

\section{Developments}

BI development may be considered in four contexts: additional functionalities, availability in the formula of open source, storage technology and data processing and, finally, as a result/ in the context of maturity models which are a quest for excellence.

A new trend of Business Performance Management (BPM), which is considered to be the successor of Business Intelligence systems, has been receiving increasingly more attention in literature from the field of Business Intelligence. Theoretically, BMP has a wider range of functionality than his younger brother BI. BMP's extended functionality, as mentioned in the literature, can include business process modeling, automatic monitoring of indicators, notification of deviations from established standards, and finally, combining different sources into one interface. Systems of BPM class focus on processes, improve their efficiency and they are designed to automate and to support these processes. The correct implementation of a BPM system offers the following benefits: faster response to changing conditions and development, increased operational efficiency, highlighted relationship with a customer, as well as improved relationship between budgeting, planning and strategy of an organization. Proper implementation of BMP also increases the return on IT investments, it allows to increase the likelihood of delivering projects in accordance with the assumptions and it reduces business risk [Ziemba and Obłąk 2012, pp. 71-85]. According to E. Ziemba and L. Obłąk, BPM systems are the next generation of Business Intelligence. However in the author's opinion, this conclusion seems to be erroneous due to two main reasons: definition of BI systems is quite ambitious, and majority of BPM features are already provided by modern Business Intelligence systems.

Before choosing a supplier of Business Intelligence system, a company should also consider an option of purchasing open source BI software. Among the biggest advantages of this approach are much lower implementation costs. In addition to a detailed comparison of the pros and cons of open source systems and professional solutions, D. Celińska and M. Lasek also conducted a SWOT analysis of open source solutions. Their conclusion is consistent with the report published by Gartner ${ }^{1}$, which concludes that a significant develop-

\footnotetext{
${ }^{1}$ The main area of activity of Gartner company is advising on decisions on information technology.
} 
ment of open source software in the area of BI is forecasted due to finding that open source solutions present more opportunities than threats to a company [Celińska and Lasek 2012, pp. 20-27].

Another important decision for a manager who wants to opt for a BI solution is the choice between solutions in the cloud and the traditional approach (which means BI implementation on a company's own IT infrastructure). M. Muntean and C. Muntan conducted a research examining the impact of implementation of Business Intelligence system in a medium-sized company in two variants: 1) Business Intelligence as a service - where system is available in the cloud $\left(\mathrm{SaaS}^{2}\right)$; and 2) BI deployment as the traditional approach in an organization (client-side infrastructure, established higher initial cost compared to $\mathrm{SaaS}$ ). Monte Carlo simulation showed that the impact of BI implementation on the level of ROE and ROI depending on the selected economic values ( $\mathrm{a}$ certain cost assumed in each variant) is much more beneficial in the first approach (SaaS) than in the traditional approach. These results were also confirmed on real data from a sample of medium-sized Romanian companies [Muntean and Muntean 2013, pp. 85-102].

In turn, M. and M. Skyba Tvrdikowa utilized their experience gained in working with BI environment by designing solutions and services in cloud computing technology based on the needs of small and medium businesses. More specifically, they examined the level of use of information technology such as BI in a survey of 150 Czech firms. As an outcome of this research, they proposed following recommendations: for micro and small enterprises -BI systems should be implemented as a SaaS; while for medium sized enterprises - BI tools are a strategic element of support which means implementing BI on a company's own IT infrastructure. Their study confirms high importance of BI tools in SMEs in the Czech Republic [Tvrdikowa and Skyba 2012, pp. 39-51]. The findings of Tvrdikowa and Skyba are also further substantiated by S. Popescu who indicates that BI provides important solution for mediumsized companies (which are without resources comparable to multinational corporations) as these systems are easy to implement and quickly improve decision-making. Popescu points out that according to research conducted by SAP company [2010], most managers know how to optimize their own department but they would like to have an understanding of how it affects the performance of their entire company. This function can certainly be provided by a BI system. According to the same study, BI systems provide powerful analytical capabilities together with the possibility of a multi-dimensional analy-

${ }^{2} \mathrm{SaaS}-$ Software as a service. 
sis, interpretation of data, filtering and access to details. At the same time, they provide an easy to use interface so that users without advanced computer knowledge can handle it [Popescu, 2012, pp. 53-63].

An important research in the area of cloud computing has been also conducted by M. Nycz. The researcher showed that only $21 \%$ of the budgets of organizations who employ traditional solutions is used for the development, the rest is spent on support of existing solutions. Replacing a part of the implemented by organizations solutions by a SaaS solution allows for the release of funds for development. However, despite the advantages of using cloud computing, Nych also identifies the following barriers: 1) Technical - poor quality of Internet connections, dependence on Internet providers; 2) Legal - storage problem and the possible leakage of personal data; 3) Mental - users often have limited confidence, mainly due to insufficient knowledge [ $\mathrm{Nycz} 2012$, pp. 53-63].

C. M. Olszak points out further issues with the effective development of business intelligence systems. According to her study, a development of Business Intelligence systems will be effective when we use the knowledge and experience based on the theory of maturity models. This concept is closely related to the achievement of an ideal state which should be followed [Lahramnn, Marx, Winter and Wortmann 2011, pp. 5-10]. However, achieving a state of maturity is associated with going through different phases of development [Fraser, Moultrie and Gregory 2002, pp. 244-249]. C. M. Olszak analyzed 13 maturity models: TDWI's Business Intelligence Model - Eckersona model, Gartner's maturity model, AMR Research's Business Intelligence/Performance Management Maturity Model - version 2, Business Information Maturity Model, Information Evolution Model by SAS company, Model Business Intelligence Maturity Hierarchy, Infrastructure Optimization Maturity Model, Business Intelligence Development Model (BIDM), Lauder of Business Intelligence (LOBI), Hawlett Package Business Maturity Model, Information Evaluation Model by SAS company, Watson model, Teradata model. By their very conception, these models are designed to answer the questions in which direction to develop BI systems within an organization. Common characteristic of almost all these models is that they appropriately name the development phase e.g. from newborn to sage, which is evaluated in various areas: types of analysis, scope, management, technology platform.

C.M. Olszak provides us with an example of four different organizations in which the implementation of BI systems significantly altered the way of doing business, long-term strategy, management of information and business processes, customer service and introducing innovative services to customers. 
Monster.com, Harrah's Entertainment Inc., Continental Airlines, and Norfolk Southern are organizations based on Business Intelligence. Each of these companies developed a BI system in an individual way, but they all have been successful in the form of the introduction of new business services, improved customer service and the development of new forms of cooperation which led to the improvement of competitiveness. A lot of similarities to the BI maturity models can be found in the actions of these companies, therefore C. M. Olszak confirms her hypothesis that "BI maturity models should be an important signpost for organizations of how BI systems need to be developed to achieve with their help measurable benefits and increasing benefits" [Olszak 2012a, pp. 9-29].

Research studies show that the vast majority of maturity models focus on technological factors such as infrastructure, data and applications and they do not take into account the key factor which is the connection between technology, functionality and usability for an organization. Soft elements are rarely mentioned, i.e. staff, organizational strategy, specific information needs. According to C. M. Olszak, as well as in this author's opinion, the mentioned above maturity models are not complete. Therefore, there is a need for a target BI maturity model which would integrate all the elements to arise in the future on the basis of research and scientific discussion [Olszak 2012b, pp. 11-26].

\section{Conclusion}

The need to increase the competence in the field of business intelligence is now a priority for many organizations. Managers become increasingly aware of how valuable, as a resource, is the data stored in the source systems. Analysis and processing of data into information is a fundamental task of BI systems. Thanks to the use of Business Intelligence tools, creation of an intelligent organization which is based on knowledge and learning from its mistakes is possible. This is achieved through storing information about the actions taken in the data warehouse of a business intelligence system.

The literature review identified the following benefits as a result of the implementation of Business Intelligence:

- The ability to start the changes which, as a result, lead to the creation of intelligent organization based on knowledge and learning.

- Improving decision making. Making decisions based on hard data, not on the basis of intuition and routine.

- The possibility of effective measurement of data sets.

- Significant reduction of time dedicated to the collection and processing of data. 
- Using advanced data visualization. Its advantage lies in much greater information capacity compared to a traditional visualization.

- The availability of advanced business analysis for small and mediumsized enterprises.

Risks identified during the implementation of the BI systems can include:

- Lack of professional change management during the implementation of the BI systems because, in itself, BI implementation leads to a reduction of goodwill due to absorbed resources needed to launch the system.

- Involvement of key employees in the process of BI implementation may result in a decrease in the efficiency of their existing activities.

Issues concerning further development of the BI systems have been also discussed. Moreover, relevant dilemmas from the point of view of a BI project sponsors' were identified and these difficulties can include a choice of BI technology tools. As a result of the published outcomes, both a solution based on cloud computing and an open source should be considered during the decision-making process, in particular by the managers of small companies.

It has been shown that further development of Business Intelligence systems dependents on the development of a theoretical model of maturity. In the literature, several models of maturity are developed, but none of them is complete since they do not pay enough attention to soft aspects, and they focus mainly on infrastructure and technology. Therefore, it seems reasonable to focus future research on the development of a complete model of maturity so that the direction of development of BI systems can be clearly determined.

\section{References}

Adamczewski P. (2012), Systemy ERP-BI w rozwoju organizacji inteligentnych [in:] Systemy inteligencji biznesowej jako przedmiot badań ekonomicznych, red. C.M. Olszak, E. Ziemba, „Studia Ekonomiczne”, nr 113, pp. 65-75.

Bara D., Knezevic N. (2013), The impact of right-time business intelligence on organizational behavior, "Interdisciplinary Management Research", vol. 9, pp. 27-42. Celińska D., Lasek M. (2012), Jaki system Business Intelligence wybrać i zastosować? A może open source?, "Informatyka Ekonomiczna”, nr 4 (26), pp. 20-27.

Chen Y. (2005), Information valuation for Information Lifecycle Management [in:] Second International Conference on Autonomic Computing, "IEEE Computer Society", Seattle. 
Fraser P., Moultrie J., Gregory M. (2002), The Use of Maturity Models/Grids as a Tool in Assessing Product Development Capability [in:] Proceedings of IEM, Cambridge, pp. 244-249.

Jin H., Xiong M., Wu S. (2008), Information value evaluation model for ILM [in:] Ninth ACIS International Conference on Software Engineering, Artificial Intelligence, Networking, and Parallel/Distributed Computing, "IEEE Computer Society", Phuket, Tajland.

Korczak J., Dudycz H., Dyczkowski M. (2012), Inteligentny kokpit dla menedżerów - koncepcja systemu [in:] Systemy inteligencji biznesowej jako przedmiot badań ekonomicznych, red. C. M. Olszak, E. Ziemba, „Studia Ekonomiczne”, nr 100, pp. 27-37.

Koronios A., Yeoh W. (2010), Critical Success Factors for Business Intelligence Systems, „Journal of Computer Information Systems”, Spring, p. 35.

Lahramnn G., Marx F., Winter R., Wortmann F. (2011), Business Intelligence Maturity: Development and Evaluation of a Theoretical Model [in:] Proceedings of the 44 Hawaii International Conference on System Science, pp. 5-10.

Maria S.D. (2009), Improving the quality of the decision making by using business intelligence solutions, "Annals of Faculty of Economics", vol. 4, issue 1, pp. 9961000 .

Muntean M., Muntean C. (2013), Evaluating A Business Intelligence Solution. Feasibility Analysis Based On Monte Carlo Method, "ECECSR Journal", nr 2, pp. 85-102.

Nycz. M. (2012), Przetwarzanie w chmurze: rewolucja czy ewolucja w przetwarzaniu danych [w:] Systemy inteligencji biznesowej jako przedmiot badań ekonomicznych, red. C.M. Olszak, E. Ziemba, „Studia Ekonomiczne”, nr 113, pp. 53-63.

Olszak C.M. (2012a), Organizacja oparta na Business Intelligence [in:] Technologie informacyjne $w$ transformacji wspótczesnej gospodarki, red. C.M. Olszak, E. Ziemba, „Studia Ekonomiczne”, 2012, nr 100, pp. 9-29.

Olszak C.M. (2012b), Analiza i ocena dorobku naukowego z zakresu Business Intelligence - wybrane zagadnienia [in:] Systemy inteligencji biznesowej jako przedmiot badań ekonomicznych, red. C.M. Olszak, E. Ziemba, „Studia Ekonomiczne", nr 113, pp. 11-26.

Orzechowski R. (2008), Budowanie wartości przedsiębiorstwa z wykorzystaniem IT, Oficyna Wydawnicza SGH, Warszawa, p. 143.

Popescu S. (2012), Business Intelligence Solutions - a Way of General Improvement of Efficiency and Effectiveness, "Review of international comparative management", vol. 13, issue 1, pp. 88-95.

Surma J. (2009), Business Intelligence, PWN, Warszawa. 
Swacha J. (2011), Metoda wyceny zbiorów danych na potrzeby zarządzania cyklem życia informacji., „Informatyka Ekonomiczna”, nr 20, pp. 108-119.

Turczyk L., Gropl M., Libau N., Steinmetz R. (2007), A method for file valuation in information lifecycle management [in:] Conference on Information Systems, "Association of Information Systems", Keystone, USA.

Tvrdikowa M., Skyba M. (2012), Wykorzystanie cloud computing $w$ business intelligence, [in:] Systemy inteligencji biznesowej jako przedmiot badań ekonomicznych, red. C.M. Olszak, E. Ziemba, „Studia Ekonomiczne”, nr 113, pp. 39-51.

Williams S., Williams N. (2003), The Business Value of Business Intelligence, "Business Intelligence Journal", vol. 3.

Ziemba E., Obłąk I. (2012), Systemy informatyczne klasy business performance management - zatożenia, funkcjonalność, technologia [in:] Technologie informacyjne w transformacji wspótczesnej gospodarki, red C.M. Olszak, E. Ziemba, „Studia Ekonomiczne", nr 100, pp. 71-85. 